\title{
THE DISTRIBUTION OF ENZYMES IN THE KIDNEYS OF SHEEP FED A HIGH AND LOW PROTEIN DIET
}

\author{
Z. FAIXOVÁ, M. LEVKUT, L. KOLODZIEYSKI, *Š. FAIX, *L. LENG \\ University of Veterinary Medicine, Košice and *Institute of Animal Physiology, Slovak Academy of \\ Sciences, Košice, Slovak Republic
}

Received May 11, 1998

Accepted June 5, 1998

\begin{abstract}
Faixová Z., M. Levkut, L. Kolodzieyski, Š. Faix, L. Leng: The Distribution of Enzymes in the Kidneys of Sheep Fed a High and Low Protein Diet. Acta vet. Brno 1998. 67: 83-87.

The distribution of 13 enzymes in the cortex, in the outer medulla and in the inner medulla of kidneys was investigated in sheep fed a high (HP) and low (LP) protein diet. Sheep on HP-diet were given a daily ration with $150.2 \mathrm{~g}$ of crude protein $(\mathrm{CP})$ and $15.2 \mathrm{MJ}$ of digestible energy (DE) while the daily intake of sheep on LP-diet was $58.3 \mathrm{~g}$ of CP and 14.2 MJ of DE. Both groups of animals were fed these diets for at least 6 weeks before the collection of kidneys. Histochemical analysis of enzymes showed that glucose-6-phosphatase and $5^{\prime}$-nucleotidase were not detectable in the kidney of sheep fed the HP-diet but they appeared in both the cortex and the outer stripe of the outer medulla of sheep on the LP-diet. Alkaline phosphatase of the inner stripe of the outer medulla and of the base of papilla was found in sheep fed the HP-diet only. Adenosine triphosphatase of the inner medulla appeared in sheep fed the LP-diet only. Changes in the distribution of other studied enzymes were only of a small magnitude. The present results demonstrate the enzyme expression of metabolic adaptation of sheep kidney to a low protein intake associated with an increased renal urea reabsorption.
\end{abstract}

Histochemistry, kidney tissue, renal, metabolic adaptation

The sheep kidney plays an important role in many metabolic and biochemical pathways, mainly in gluconeogenesis, both from amino acid and non-nitrogenous glucose precursors. The adaptive changes in metabolic activity of sheep kidney associated with a modified renal function due to altered dietary protein intake are not fully understood yet. Protein intake in sheep and also in other ruminants has a significant effect on the renal concentrating ability (Schmidt-Nielsen 1979), on the urea reabsorption in tubules (Faix et al. 1988a) and in renal pelvis (Cirio and Boivin 1990) as well as on glomerular filtration rate (Leng et al. 1985; Faix et al. 1988b; Skrzypczak et al. 1996). Just an increased delivery of some amino acids to sheep kidney due to their direct intrarenal infusion can induce a considerable change in many renal functions (Leng et al. 1994). The adaptation of sheep kidneys to an increased renal reabsorption of urea during low protein intake is expressed also by morphological changes in the epithelium in some nephron segments in both the cortex and medulla (Kočišová et al. 1997). Therefore it may be assumed that renal urea retention in sheep is accompanied also by changes in expression of enzymes in the kidney tissue.

The existence of major biosynthetic and catabolic pathways of intermediary metabolism in the mammalian kidney has been known for a long time. Metabolism of the renal cortex is characterized mainly by fatty acid oxidation and gluconeogenesis (Weideman and 
Krebs 1969). In contrast, the renal medulla as the kidney compartment with the largest urea recycling, reveals a high rate of aerobic and anaerobic glucose metabolism and it probably depends on glucose as a respiratory fuel (Lee and Peter 1969; A bodeely and Lee 1971).

The aim of this experiment was to describe the effect of low and high protein intake on the distribution of 13 enzymes (see the list of studied enzymes below) in both the cortex and medulla of sheep kidney.

\section{Materials and Methods}

\section{Experimental animals and diet}

Twelve sheep (Ovis aries) of Merino breed, weighing from $30-35 \mathrm{~kg}$ were 15 months of age approximately. The animals were housed individualy in cages and they received water and minerals ad libitum. The sheep were divided in two groups with different protein intakes. Six sheep had a diet with high protein (HP) content and another six sheep were fed a diet with low protein (LP) content. The daily ration of sheep on HP-diet consisted of $500 \mathrm{~g}$ hay, $500 \mathrm{~g}$ barley, $250 \mathrm{~g}$ wheat bran, containing $150.2 \mathrm{~g}$ of crude protein and $15.2 \mathrm{MJ}$ of digestible energy. Animals of the LP-group received daily a diet consisting of $1000 \mathrm{~g}$ barley straw, $150 \mathrm{~g}$ wheat bran, $300 \mathrm{~g}$ corn starch, containing $58.3 \mathrm{~g}$ of crude protein and $14.18 \mathrm{MJ}$ of digestible energy. The animals were kept on the experimental diets for at least 6 weeks before sample collection.

\section{Collection and handling of tissue samples from kidneys}

The left kidneys were removed from sheep after laparotomy carried out in pentobarbitone anaesthesia $\left(25 \mathrm{mg}^{\circ} \mathrm{kg}^{-1}\right.$ b. m.). Tissue samples collected from the cortex, from the outer and the inner medulla of kidney were immediately frozen in liquid nitrogen $\left(-180^{\circ} \mathrm{C}\right)$. The whole procedure from clamping of renal pedicle to freezing of tissue samples in liquid nitrogen took less than $1.5 \mathrm{~min}$.

For histochemistry, samples of kidney tissue were divided into outer and inner cortex, inner and outer stripe of outer medulla, and base and tip of papilla. Each fixed slice was cut to sections $5 \mu \mathrm{m}$ thick on a cryostat with a cabinet temperature of $-18{ }^{\circ} \mathrm{C}$. Thereafter the sections were thawed into slides coated with $0.1 \%$ polyly'sine solution and air-dried for $10 \mathrm{~min}$ at room temperature to ensure a good adherence.

Enzyme analysis

The distribution of the following 13 enzymes was studied: glucose-6-phosphatase (G-6-P, EC 3.1.3.9.), alkaline phosphatase (AF, EC 3.1.3.1.), 5'-nucleotidase (5'-N, EC 3.1.3.5.), adenosine triphosphatase (ATP, EC 3.6.1.3.), acid phosphatase (AF, EC 3.1.3.2.), peroxidase (PO, EC 1.11.1.7.), succinate dehydrogenase (SDH, EC 1.3.99.1.), glycerol-3-phosphate dehydrogenase (G-3-P, EC 1.1.99.5.), lactate dehydrogenase (LDH, EC 1.1.1.27.), malate dehydrogenase (MDH, EC 1.1.1.37.), glucose-6-phosphate dehydrogenase (G-6-P DH, EC 1.1.1.49.), glutamate dehydrogenase (GDH, EC 1.4.1.3.) and $\beta$-D-galactoside galactohydrolase ( $\beta$-GAL, EC 3.2.1.23.).

The procedures used to determine the enzymes were described by Pearse (1960), Sigma Chemicals Company (1963), Cohen (1959), Allen and Slater (1960).

Stained tissue sections were inspected under the light microscope at a magnification of 180 to determine the distribution and relative activity of the enzymes. Relative activities of these enzymes in the tissues were visually scored on a scale: 0 -none, ${ }^{*}$ - slight. $*^{*}$ - moderate, $* * *$ - expressive. Each enzyme from every sheep was evaluated in triplicates.

\section{Results}

Our results show (Tab. 1) that only 4 enzymes (glucose-6-phosphatase, alkaline phosphatase, 5 '-nucleotidase and adenosine triphosphatase) among the 13 we investigated, had largely different appearance in tissue of kidneys of sheep fed the low (LP) or high (HP) protein diet.

Glucose-6-phosphatase was not found in the kidney of sheep fed the HP-diet but it was determined in both the outer and inner cortex and in the outer stripe of the outer medulla of sheep on the LP-diet.

Differences in the appearance of alkaline phosphatase between sheep on the HP- and LPdiet were found predominantly in the inner stripe of the outer medulla and the base of papilla. Alkaline phosphatase in these two zones of kidney was demonstrated in sheep fed the HPdiet only. 
Table 1

The distribution of 13 enzymes in the sheep kidney after 6 weeks at diet with high $(*)$ and low $(+)$ protein content. Relative activity of the enzymes in the tissue is depicted as:

$0=$ none, ${ }^{*}$ or $+=$ slight, ${ }^{* *}$ or $++=$ moderate, $* * *$ or $+++=$ expressive.

\begin{tabular}{|c|c|c|c|c|c|c|}
\hline \multirow[b]{3}{*}{ Enzyme } & \multirow{2}{*}{\multicolumn{2}{|c|}{ Cortex }} & \multicolumn{4}{|c|}{ Medulla } \\
\hline & & & \multicolumn{2}{|c|}{ Outer } & \multicolumn{2}{|c|}{ Inner } \\
\hline & Outer & Inner & $\begin{array}{l}\text { Outer } \\
\text { Stripe }\end{array}$ & $\begin{array}{l}\text { Inner } \\
\text { Stripe }\end{array}$ & $\begin{array}{l}\text { Base of } \\
\text { Papilla }\end{array}$ & $\begin{array}{l}\text { Tip of } \\
\text { Papilla }\end{array}$ \\
\hline G-6-P & $0 /++$ & $0 /++$ & $0 /+$ & $0 / 0$ & $0 / 0$ & $0 / 0$ \\
\hline $\mathrm{AF}$ & $* * * /+++$ & $* * * /+++$ & $* * /+$ & $* / 0$ & $* / 0$ & $0 / 0$ \\
\hline $5^{\prime}-\mathrm{N}$ & $0 /+$ & $0 /++$ & $0 /+$ & $0 / 0$ & $0 / 0$ & $0 / 0$ \\
\hline ATP & $* * /++$ & $* * * /+++$ & $* * /+++$ & $* /++$ & $0 /+$ & $0 /+$ \\
\hline $\mathrm{KF}$ & $* * * /+++$ & $* * * /+++$ & $* * * /+++$ & $* * /++$ & $* /+$ & $* /+$ \\
\hline $\mathrm{PO}$ & $* * /+++$ & $* * /+++$ & $* * * /+++$ & $* * /++$ & $* * /++$ & $* * /++$ \\
\hline SDH & $* * * /++$ & $* * * /+++$ & $* * /+++$ & $* * /++$ & $* / 0$ & $0 / 0$ \\
\hline LDH & $* * /+++$ & $* * /+++$ & $* * * /+++$ & $* * * /++$ & $* * /+$ & $* /+$ \\
\hline G-3-P & $* * /++$ & $* * /+++$ & $* * * /+++$ & $* /++$ & $* /+$ & $0 / 0$ \\
\hline $\mathrm{MDH}$ & $* * /++$ & $* * /+++$ & $* * * /+++$ & $* * /++$ & $* * /+$ & $* /+$ \\
\hline G-6-P DH & $* * * /+++$ & $* * * /+++$ & $* * /+++$ & $* * /++$ & $* * /+$ & $* * /+$ \\
\hline GDH & $* * * /++$ & $* * * /+++$ & $* * /+++$ & $* /++$ & $* /+$ & $* / 0$ \\
\hline$\beta-G A L$ & $* * * /+++$ & $* * * /+++$ & $* * /+++$ & $* * /++$ & $* /++$ & $* /++$ \\
\hline
\end{tabular}

G-6-P = glucose-6-phosphatase; $\mathrm{AF}=$ alkaline phosphatase; $5^{\prime}-\mathrm{N}=5^{\prime}$-nucleotidase; $\mathrm{ATP}=$ adenosine triphosphatase; $\mathrm{KF}=$ acid phosphatase; $\mathrm{PO}=$ peroxidase; $\mathrm{SDH}=$ succinate dehydrogenase; $\mathrm{LDH}=$ lactate dehydrogenase; G-3-P = glycerol-3-phosphate dehydrogenase; $\mathrm{MDH}=$ malate dehydrogenase; G-6-P DH = glucose-6-phosphate dehydrogenase; $\mathrm{GDH}=$ glutamate dehydrogenase; $\beta-\mathrm{GAL}=\beta$-D-galactoside galactohydrolase .

Markedly largest differences were found in 5'-nucleotidase. This enzyme could not be detected in the kidney of sheep on the HP-diet but it appeared in both the outer and inner cortex and in the outer stripe of the outer medulla of animals on the LP-diet.

Striking differences were found also in appearance of adenosine triphosphatase in the inner medulla. Its presence in this kidney zone was confirmed in sheep fed the LP-diet only.

Some small differences in the appearance of succinate dehydrogenase (SDH) and glutamate dehydrogenase (GDH NAD) were determined in the inner medulla. SDH was not present in this kidney zone of sheep on the LP-diet while a small amount was detected at the base of papilla in animals on HP-diet. Similarly, GHD NAD could not be find in the tip of kidney papilla from sheep fed the LP-diet but some slight appearance was revealed in this kidney structure of sheep fed the HP-diet.

\section{Discussion}

The distribution of 13 enzymes under study gives further support to the general knowledge that enzyme activities are highest in the cortex and lowest in the inner medulla of sheep kidney similar to other mammals. Regarding the differences in enzyme activities of the kidney tissue between the high and low protein intake groups larger changes were found in four enzymes only.

A typical phenomenon of LP-diet intake is a reduced glomerular filtration rate. There are more metabolic products related to glomerular filtration rate (Leng et al. 1995). One of them is also 5'-AMP (Urbaitis 1984) which is known to increase the adenosine tissue concentrations (Miller et al. 1978; Osswald et al. 1982) and they both seem to be related to the activity of 5'- nucleotidase (Ramos-Salazar and Baines 1986). In our experiment the presence of 5 '- nucleotidase was detected in the cortex tissue of sheep fed the low protein diet only. 
Results from the appearance of 5'-nucleotidase and glucose-6-phosphatase confirm that an intake of low protein diet in sheep is accompanied by catabolic proceses. This is suggesting a more intensive gluconeogenesis due to reduced supply of energy substrates from food in sheep kept on the low protein intake. Increased activity of glucose-6phosphatase in kidney tissue of sheep on LP-diet was found also by Rabinowitz et al. (1973). The activity of this enzyme is significantly increased in proximal tubule also during starvation (Burch et al. 1978).

Differences in the appearance of adenosine triphosphatase and alkaline phosphatase were noted only in the inner medulla and in the inner stripe of the outer medulla or in the base of papilla, respectively. These are the zones of kidney with enlarged intrarenal urea recycling in sheep adapted to low protein intake (Tebot et al. 1998). A direct relation of these enzymes activity to the urea transport in tubular cells of sheep nephron does not seem to be involved. One of the reasons is that a micropuncture study of the sheep kidney did not confirm the concept of active urea transport which would be dependent on energy derived from anaerobic metabolism ( Faix et al. 1991).

In conclusion, our findings of various appearances of some enzymes in the kidney tissue of sheep fed diets with different protein content suggest metabolic adaptation of kidneys to a low protein intake associated with increased urea reabsorption.

\section{Výskyt enzýmov v obličkách oviec na vysoko- a nízkodusíkovej diéte}

Výskyt 13 enzýmov bol sledovaný v kôre, vonkajšej a vnútornej dreni obličiek oviec kŕmených vysoko- (HP) a nízkoproteinovou (LP) diétou. Ovce s HP diétou mali denný príjem 150,2 g hrubého proteínu (CP) a 7,22 MJ netto energie laktácie (NEL) a s LPdiétou $58,3 \mathrm{~g} \mathrm{CP}$ a 6,15 MJ NEL. Obe skupiny zvierat boli kŕmené diétami 6 týždňov pred odberom obličiek. Histochemické analýzy enzýmov ukázali, že glukózo-6-fosfatáza a 5'nukleotidáza neboli merateIné $\mathrm{v}$ obličkách oviec kŕmených HP diétou, ale boli zistené $\mathrm{v}$ oboch častiach kôry a vonkajšom prúžku vonkajšej drene u oviec na LP diéte. Alkalická fosfatáza vo vnútornom prúžku vonkajšej drene a bázy papily bola zistená iba u oviec kŕmených HP diétou. Adenozíntrifosfatáza vnútornej drene bola zistená iba u oviec kŕmených LP diétou. Zmeny v distribúcii ostatných enzýmov boli málo výrazné. Zmeny v distribúcii enzýmov sú odrazom metabolickej adaptácie na nízky príjem bielkovín diétou a sú v spojení so zvýšenou reabsorpciou močoviny v obličkách.

\section{References}

ABODEELY, D. A., LEE, J. B. 1971: Fuel of respiration of outer renal medulla. Am. J. Physiol. 220: 1693-1700

ALLEN, J. M., SLATER, J. J. 1960: The properties of the lactic dehydrogenase diphosphopyridine nucleotidediaphorase system in the epidydimis of the mouse. J. Histochem. Cytochem. 8: 347

BURCH, H. B., NARINS, R. G., CHU, CH., FAGIOLI, S., CHOI, S., McCARTHY, W., LOWRY, O. H. 1978: Distribution along the rat nephron of three enzymes of gluconeogenesis in acidosis and starvation. Am. J. Physiol. 235(3): F246-F253

CIRIO, A., BOIVIN, R. 1990: Urea recycling from the renal pelvis in sheep: a study with [14C] urea. Am. J. Physiol. 258: F1196-F1202

COHEN, R. B. 1959: Histochemical localization and metabolic significance of glucose-6-phosphate dehydrogenase system in adrenal cortex. Proc. Soc. Exp. Biol. Med. 101: 405

FAIX, S., LENG, L., SZANYIOVÁ, M., BOĎ, K. 1988a: Effect of dietary protein intake on tubular reabsorption of urea in sheep. Physiol. Bohemoslov. 37(6): 493-501

FAIX, Š., LENG, L., SZANYIOVÁ, M., BODA, K. 1988b: Creatinine and inulin clearance at the different nitrogen and energy intake. Comp. Biochem. Physiol. 91A: 689-691

FAIX. S., LENG, L., SZANYIOVÁ, M. 1991: Micropuncture study of the kidney in sheep: Effects of iodoacetate on renal urea handling. Comp. Biochem. Physiol. 100A: 159-162 
KOČIŠOVÁ, J., SZANYIOVÁ. M., FAIX, Š.. LENG, L. 1997: The effect of low protein diet on the epithelium of nephron segments in sheep. Vet. Med.- Czech 42: 93-95 (In Slovak)

LANG, F., OTTL, I., HAUSINGER, D., DEETJEN, P., AHLOUlAY, M., BANKIR, L. 1995: Renal hemodynamic response to intravenous and oral amino acids in animals. Seminars in Nephrology, 15(5): 415 418

LEE, J. B., PETER, H. M. 1969: Effect of oxygen tension on glucose metabolism in rabbit kidney cortex and medulla. Am. J. Physiol. 217: 1464-1471

LENG, L., SZANYIOVÁ, M., FAIX, Š., CIRIO, A. 1994: Renal response of sheep fed a low protein diet to intraportal infusion of arginine and glycine. Comp. Biochem. Physiol. 108A (2/3): 343-347

LENG, L., SZANYIOVÁ, M., BODAA, K. 1985: The renal response of sheep to a low dietary nitrogen intake. Physiol. Bohemoslov. 34: 147-159

MILLER, W. L., THOMAS, R. A., BERNE, R. M. 1978: Adenosine production in the ischaemic kidney. Circ. Res. 43: 390

OSSWALD, H., HERMES. H. H., NABAKOWSKI, G. 1982: Role of adenosine in signal transmission of tubuloglomerular feedback. Kidney Int. (suppl.) 22: S136

PEARSE, A. G. E. 1960: Histochemistry, Theoretical and Applied (2nd Ed.). J. and A. Churchill Ltd., London

RABINOVITZ, L., GUNTHER, R. A., SHOJI, E. S., FREEDLAND, R. A. 1973: Effects of high and low protein diets on sheep renal function and metabolism. Kidney International 4: 188-207

RAMOS-SALAZAR, A., BAINES, A. D. 1986: Role of 5'-nucleotidase in adenine-mediated vasoconstriction during hypoxia. J. Pharmacol. Exp. Ther. 236: 494

SCHMIDT-NIELSEN, B. 1979: Urinary concentrating processes in vertebrates. Yale J. Biol. Med. 52: 545-561

Sigma Chemical Company. 1963: Histochemical demonstration of acid and alkaline phosphatase. Technical Bull. No. 85, Sigma Chemical Co., St. Louis, MO

SKRZYPCZAK, W. F., OZGO, M., JANUS. K., SKOTNICKA, E., JANKOVIAK, D., MUSZCZYNSKI, Z., SUSZYCKA. J. 1996: The influence of increased protein content in the diet on renal functions in calves. Acta vet. Brno, 65: 115-121

TEBOT, I., FAIX, Š., SZANYIOVÁ, M., CIRIO, A., LENG, L. 1998: Micropuncture study on urea movements in the kidney cortical tubules of low protein fed sheep. Vet. Res. 29: 99-105

URBAITIS, B. K. 1984: Effect of ischemia and hypertonic saline loading on renal adenine nucleotides. Renal Physiol. 7:22

WEIDEMAN, M. J., KREBS, H. A. 1969: The fuel of respiration of rat kidney cortex. Biochem. J. 112: 149-166 